\title{
Review
}

\section{Disinhibition of neurite growth to repair the injured adult CNS: Focusing on Nogo}

\author{
R. R. Gonzenbach ${ }^{\mathrm{a}, *}$ and M. E. Schwab ${ }^{\mathrm{b}}$ \\ ${ }^{a}$ Brain Research Institute, University of Zürich, Winterthurerstrasse 190, 8057 Zürich (Switzerland), \\ Fax: + 41446353303, e-mail: gonzenbach@hifo.unizh.ch \\ ${ }^{\mathrm{b}}$ Deptartment of Biology, Swiss Federal Institute of Technology (ETH), Winterthurerstrasse 190, \\ CH-8057 Zürich (Switzerland)
}

Received 5 April 2007; received after revision 28 September 2007; accepted 1 October 2007

Online First 3 November 2007

\begin{abstract}
Investigations into mechanisms that restrict the recovery of functions after an injury to the brain or the spinal cord have led to the discovery of specific neurite growth inhibitory factors in the adult central nervous system (CNS) of mammals. Blocking their growth-suppressive function resulted in disinhibition of axonal growth, i.e. growth of cultured neurons on inhibitory CNS tissue in vitro and regeneration of injured axons in vivo. The enhanced regenerative and compensatory fibre growth was often accompanied by
\end{abstract}

a substantial improvement in the functional recovery after CNS injury. The first clinical studies to assess the therapeutic potential of compounds that neutralize growth inhibitors or interfere with their downstream signalling are currently in progress. This review discusses recent advances in the understanding of how the 'founder molecule' Nogo-A and other glialderived growth inhibitors restrict the regeneration and repair of disrupted neuronal circuits, thus limiting the functional recovery after CNS injuries.

Keywords. Regeneration, plasticity, myelin, CNS repair, spinal cord injury, stroke.

\section{Introduction}

In mammals, an injury to the adult central nervous system leads to irreversible functional impairments. For example, after a cervical spinal cord injury (SCI), the ability to walk or to grasp an object is impaired and there is little recovery of these motor functions following the acute phase after large injuries. Similarly, after stroke, various functions are impaired depending on which brain regions are damaged. After large strokes, substantial recovery is rare and functional deficits usually persist for the rest of life. This lack of significant functional recovery after CNS

* Corresponding author. injury corresponds with the failure of mature central neurons to effectively regenerate axons. Lesioned nerve fibres usually retract and form dystrophic end bulbs [1]. Occasionally, the proximal stumps of cut axons start to grow short sprouts but this sprouting response comes to a halt. The sprouting collaterals are not able to grow significantly and often retract $[1,2]$. This is in sharp contrast to the response of injured axons in the peripheral nervous system, which regenerate vigorously over long distances and re-establish functioning synaptic contacts with peripheral muscles, a process which can lead to functional restoration. This observation inspired the landmark experiments of Aguayo and colleagues in the early 1980s [3]: they showed that after spinal cord injury, CNS axons readily grew into a peripheral nerve graft transplanted 
into the wound. This demonstrated, for the first time, that adult, injured central neurons are able to regenerate long axons under favourable conditions (including basal lamina tubes and Schwann-cellderived trophic factors) of the peripheral-nerve microenvironment.

In the late 1980s, our laboratory undertook experiments to investigate the molecular differences between central and peripheral nerve tissue. We found that explanted, cultured dorsal root ganglion neurons grew into explants of sciatic nerves, but not into optic nerves despite the presence of high concentrations of trophic factors [4]. Subsequently, myelin extracted from peripheral nerves was shown to be growth permissive whereas CNS myelin strongly inhibited nerve growth [5]. We went on to isolate a membrane protein from CNS myelin that strongly inhibited neurite growth, 'IN-250', which is now called NogoA [5-7]. Antibodies raised against this inhibitory protein neutralized the growth-restricting properties of oligodendrocyte myelin in vitro [8]. However, the most encouraging results achieved with these antibodies was the substantial regeneration of cut fibre tracts in vivo [9]. Importantly, this increased regeneration was accompanied by an impressive recovery of lost motor function $[10,11]$.

The discovery and characterization of myelin-associated neurite growth inhibitory proteins, in particular Nogo-A, has opened the door to a new field in regeneration research. In the wake of this breakthrough, other molecules were found to suppress neurite growth in the adult CNS. Most of them are located in the myelin sheaths of oligodendrocytes or are secreted into the extracellular matrix after injury.

\section{Nogo-A}

Nogo-A, -B and -C are splice variants of the nogo gene that was identified on the basis of peptide sequences of IN-220/250, isolated from CNS myelin $[6,7,12,13]$. All three Nogo isoforms share a common carboxyl terminus of 188 amino acids which contains two long hydrophobic domains and a short loop of 66 amino acids between the two hydrophobic domains, called Nogo-66. The common C-terminus is a reticulon homology domain (RHD) and assigns the Nogo gene to the Reticulon protein family, with Nogo being Reticulon 4 (RTN4). However, the common Nogo-A/B $\mathrm{N}$-terminus and the large, 800-amino-acid-long NogoA-specific region are unique to Nogo and have no homology to the RTN genes. Reticulons are highly conserved, and reticulon-like genes occur in all eukaryotes. Nogo-A, like other reticulons, contains an endoplasmatic reticulum (ER) retention motif and is highly enriched in the ER, in addition to its location in the cell membrane [7, 8, 12-14]. A recent report suggests that Nogo/RTN4 might be involved in shaping the tubular morphology of the ER [15].

Although a large part of Nogo-A is found intracellularly, it is also present on the cell surface and at least three active sites are exposed to the extracellular space: the Nogo-66 domain, which is close to the Cterminus and common to all three Nogo isoforms, inhibits neurite growth and induces growth cone collaps $[12,16]$. A second active site (also called the central inhibitory domain) is located within the large 800-amino-acid Nogo-A-specific domain and strongly inhibits neurite outgrowth and cell spreading and induces growth cone collapse [16]. The third active site is found in the Nogo-A/B-specific N-terminus which inhibits spreading of cultured fibroblast [16] and was recently shown to promote adhesion of vascular cells and to stimulate endothelial cell migration $[17,18]$.

The glycoprotein $\mathrm{NgR}$, which is widely expressed in many neurons, has been characterized as a receptor subunit that binds to the Nogo-66 site [19-21]. $\mathrm{NgR}$ is a GPI-linked cell surface protein that lacks an intracellular domain and requires either p75 [22, 23] or TROY $[24,25]$ as co-receptors to mediate signal transduction across the cell membrane. Both are transmembrane proteins of the tumour necrosis factor receptor (TNFR) family. Another co-receptor, LINGO-1, acts as an adaptor protein and seems to be required for Nogo-A signalling [26]. Interestingly, two other myelin-associated growth inhibitors, MAG and OMgp, bind to $\mathrm{NgR}$ with high affinity as well. This means that three structurally unrelated myelin-associated inhibitory molecules, Nogo-A, MAG and OMgp, converge on a single receptor complex and share a common intracellular signalling pathway [22, 27-30].

Several in vitro and in vivo observations indicate that another yet unknown receptor mechanism may mediate Nogo-A-specific signalling. Although the NogoA-specific central region does not bind to $\mathrm{NgR}$, it inhibits neurite outgrowth and prevents spreading of different cell types [16]. Moreover, corticospinal tract neurons of $\mathrm{ngr}^{--}$or $\mathrm{p} 75^{-/-}$mice do not regenerate after SCI [31-33] but regenerate vigorously after application of antibodies directed against the Nogo-Aspecific domain in vivo (see below), indicating that another receptor or an additional receptor subunit may be of importance for the in vivo suppression of axonal growth. 
Nogo-A is expressed in oligodendrocyte myelin and in some subpopulations of neurons

Nogo-A is highly expressed in oligodendrocytes of higher vertebrates, where it localizes mainly to the outer and innermost adaxonal myelin sheath (i.e. at the axon-oligodendrocyte contact zone) and to synaptic sites [34, 35].

The time of myelination of different pathways coincides with the age at which their regenerative capability is lost, pointing to the crucial contribution of the myelin-associated inhibitors such as Nogo-A in forming the growth-suppressive environment of the adult CNS [36]. During development, oligodendrocyte Nogo-A expression follows the course of myelination: in the developing cerebellum, for example, nogo-a mRNA first appears in oligodendrocytes in deep cerebellar regions at P5 and later on, at P9, Nogo-Apositive oligodendrocytes are found towards the distal ends of the folia in the white matter, correlating with the course of myelination [34,37].

During development, Nogo-A is also expressed in subpopulations of neurons [34,38-43], whereas in the adult CNS, neuronal Nogo-A is down-regulated in most of these regions. Neuronal expression of Nogo-A is tightly regulated during development; for example, olfactory receptor neurons and cerebellar granule cells were shown to have high levels of Nogo-A protein or mRNA during differentiation and migration, but after maturation, Nogo-A was virtually absent $[34,39]$. In growing axons, Nogo-A preferentially localizes to the growth cone and to axonal branching points [39, 41, 43, 44]. Furthermore, radial glia cells, which are crucial for cortical development, express high levels of Nogo-A [43].

In contrast to mammals, Nogo-A is not found in the CNS myelin of lower vertebrates like fish or salamander [45, 46], whose CNS has a much higher regenerative potential [47-51]. Salamander, for example, can completely regenerate an injured spinal cord with full restoration of functions [50]. In contrast, frogs do express Nogo-A in myelin [46]. Accordingly, their regenerative potential is limited, and adult frogs do not recover from spinal cord transection [52].

Interestingly, Nogo-A expression levels are also known to be altered in a number of CNS diseases. For example, in amyotrophic lateral sclerosis (ALS), Nogo-A is up-regulated in muscles and spinal cord motoneurons [53] and might be involved in the pathophysiology of the disease [54]. The expression of Nogo-A in muscle tissue could also be used as an early diagnostic [53] and prognostic [55] marker for ALS. Furthermore, soluble Nogo-A fragments are found in the cerebrospinal fluid of patients with multiple sclerosis (MS) [56, 57]. In experimental autoimmune encephalomyelitis (EAE), a widely used animal model for MS, vaccination against a Nogo-A fragment or passive immunization with antiNogo-A antibodies attenuate clinical signs, demyelination and axonal damage $[58,59]$.

After brain or spinal cord trauma, overall Nogo-A protein or mRNA levels are mostly unaltered $[34,38$, 41]. After the Wallerian degeneration of axons distal to an injury site, the myelin sheaths persist for a long time in the CNS. Indeed, Nogo-A was still detectable in degenerated fibre tracts of human spinal cord 3 years after spinal cord injury [60].

\section{The intracellular signalling pathways of Nogo-A involve $\mathrm{RhoA}$ and $\mathrm{Ca}^{2+}$}

CNS neurons respond to Nogo-A with growth cone collapse and the arrest of neurite growth, suggesting an intracellular signalling mechanism that ultimately acts on cytoskeletal dynamics. Activation of RhoA seems to be a major downstream signalling mechanism of Nogo-A [61-64]. RhoA is a GTPase of the Rho family and is known for its central role in the signal transduction of axonal guidance molecules during development. Rho-A together with two other members of the same family, Rac1 and Cdc42, interact with a series of downstream effectors to regulate the dynamics of the actin cytoskeleton [for reviews see refs. 65-68]. Active RhoA activates Rho kinase (ROCK) which in turn can phosphorylate several other effectors. Injured axons are able to grow on an inhibitory myelin substrate when RhoA or ROCK are inactivated [62-64]. Further downstream signalling may involve the phosphorylation of cofilin by LIM kinase [69].

Nogo-A also initiates a rise in intracellular calcium, which mediates collapse of growth cones [23,70]. Two additional signal mediators were found to be activated as well: protein kinase $\mathrm{C}$ (PKC) $[71,72]$ and epidermal growth factor receptor (EGFR) [73]. These pathways may act in parallel or in sequence with RhoA.

Interestingly, Nogo-A shares some of its downstream effectors with other myelin associated inhibitors of neurite growth as well as with chondroitin sulphate proteoglycans (see below) [73-76]. Targeting these downstream effectors of Nogo-A with specific blocking compounds therefore prevents the signalling of a number of different neurite growth inhibitors.

\section{Several other myelin-associated molecules also suppress neurite growth}

Several components of CNS myelin have been shown to inhibit regrowth of injured neurons. Myelin-associated glycoprotein (MAG) $[77,78]$ and oligodendrocyte myelin glycoprotein (OMgp) [27] are enriched in 
oligodendrocytes. Although both are structurally unrelated to Nogo-A, they can bind to the $\mathrm{NgR} / \mathrm{p} 75 /$ Lingo-1 receptor complex. The blockade of this pathway promotes neurite growth in vitro, but there is no evidence so far that acute in vivo neutralization of MAG or OMgp or gene knockout leads to regeneration or improves functional recovery. Versican V2 and brevican, both CSPGs, are constitutively present in myelin and also suppress neurite growth $[79,80]$. In addition, some repulsive axon guidance cues that play a role in development continue to be expressed in oligodendrocytes in adult animals and have been implicated as inhibitors of axonal regeneration. Ephrin B3, best known for its function as a midline repellent for growing corticospinal tract (CST) fibres during development, is expressed in myelinating oligodendrocytes in adult mammals and strongly inhibits axonal growth in vitro [81]. Mice which lack EphA4, a receptor for Ephrin B3, show increased axonal regeneration in vivo [82]. Another regulator of axonal pathfinding during development, Semaphorin $4 \mathrm{D}$, is also present in myelinating oligodendrocytes and inhibits neurite growth [83].

\section{The glial scar also contains growth-inhibitory molecules that impede the regeneration of cut axons through the lesion site}

Myelin is not the only source of neurite growth inhibition in the adult CNS. CNS injuries trigger a cascade of cellular, vascular and molecular events that eventually lead to the formation of a glial scar: the disruption of the blood-brain barrier results in the recruitment of inflammatory cells, neutrophils and macrophages that invade the disrupted tissue and, together with activated resident microglia cells, start to phagocytose cell debris. They release a wealth of inflammatory mediators such as cytokines and prostaglandins, which in turn attract more inflammatory cells, including T cells, to the injury site and together produce a complex concert of cellular and molecular factors that can be supportive or inhibitory for neurite growth [for reviews on inflammation and regeneration see refs. 36, 84].

At the same time, glial cells, notably activated astrocytes and oligodendrocyte precursor cells, together with invading meningeal cells start to produce chondroitin sulphate proteoglycans (CSPGs) and release them into the extracellular space [85]. Different species of CSPGs, such as NG2, neurocan, versican, phosphacan and brevican [79, 86-90] are strong inhibitors of neurite growth and accumulate at and around the lesion site within days after an injury. These secreted CSPGs are an important component of the glial scar and may persist for months [91, 92], impeding sprouting and regenerating axons from crossing the lesion site.

Accumulated CSPGs can be enzymatically degraded by repeatedly injecting bacterial chondroitinase $\mathrm{ABC}$ into the injured tissue [93]. This elimination of inhibitory CSPGs was shown to increase effectively the regeneration of cut axons through the glial scar and thus improve the recovery of motor and sensory functions [93]. Using the GFAP promotor to transgenically express chondroitinase $\mathrm{ABC}$ in astrocytes led to increased growth of CST axons into the lesion site but did not yield an improved recovery of motor functions [94] [The role of CSPGs after CNS injury is reviewed in refs. 85, 95].

\section{Myelin-associated inhibitors and CSPGs stabilize existing connections and suppress plasticity in the mature CNS}

The occurrence of different inhibitory molecules in the CNS of adult mammals suggests that they play a vital role. Increasing evidence indicates that myelin and its associated inhibitors of axonal growth control and restrict fibre growth in the adult CNS. For example, the onset of myelination correlates with the postnatal decline in the plastic potential in various axonal pathways as shown by the decline of the plasticity marker GAP-43 concurrently with myelination [96]. Moreover, the CNS remains permissive for neurite growth if myelination is blocked by neonatal X-ray irradiation [97].

Myelin and myelin-associated inhibitors appear in the CNS after the completion of axon growth. Intriguingly, they might actually be involved in terminating the neurite growth phase during postnatal CNS development. Following axonal pathfinding and initial circuit formation in early development, a second, activity-dependent process adjusts and fine-tunes the neuronal circuits in 'critical periods' during early postnatal life. These critical periods, characterized by a high plasticity of connections, are restricted to welldefined time windows in early life. For example, ocular dominance columns in the visual cortex are fine-tuned during a short postnatal time period: during this critical period, monocular deprivation by experimentally closing one eye leads to the expansion of the ocular dominance columns of the contralateral, non-deprived eye [98].

Two papers have shown that Nogo-A, via its receptor $\mathrm{NgR}$, and CSPGs are involved in closing the critical period for ocular dominance in the visual cortex. Enzymatic degradation of CSPGs with chondroitinase $\mathrm{ABC}$ was shown to restitute plasticity for monocular 
deprivation in adult rats, leading to a shift of ocular dominance to the non-deprived eye after unilateral lid suture [99]. Genetic deletion of Nogo-A/B or the Nogo receptor subunit $\mathrm{NgR}$ was found to extend the closure of the critical period for monocular deprivation in young adult mice [100]. It seems, therefore, that Nogo and CSPGs actively contribute to the consolidation of neuronal circuits during CNS maturation. They restrict plasticity and may prevent axons from aberrant growth in the adult CNS [96, 101, 102]. The lack of axonal regeneration would therefore be the price to pay for the stabilization of a complex nervous system [96, 102-104].

\section{Blocking Nogo-A function after SCI}

The consequences of SCI are complex: vast numbers of axons that carry sensory information from the spinal cord to the brain and motor and autonomic system commands from the brain to the spinal cord are partly or, in rare cases, completely disconnected from their specific targets. At the level of the injury, interneurons and motoneurons are destroyed. Yet, about half of spinal-cord-injured patients in western countries show some limited recovery in the first months after the injury [105]. Patients with lesions that do not completely interrupt all ascending and descending pathways are more likely to spontaneously recover some of the lost functions. These functional improvements, however, are variable and depend on the lesion anatomy. Most patients have to cope with permanent functional deficits. Depending on the level and the severity of the injury, many patients suffer from motor and sensory deficits and malfunctions such as pain and spasticity for the rest of their life. Often, apparently small functional improvements, e.g. regaining some hand function or being able to stand up from the wheelchair and support the own weight, can mean a lot in the daily life of a victim of SCI and may decide between complete dependence or living in autonomy.

Such spontaneous functional improvements are largely due to adaptive changes in the neuronal circuitries of the brain and the spinal cord. Axotomized neurons around the lesion were shown to up-regulate growth proteins such as GAP-43, and some transected axons may sprout and grow collaterals and may form new functional connections [106, 107].

However, reorganization of the injured CNS is limited, due in part to restrictions imposed by the inhibitory CNS environment. Attempts of axons to regenerate are transitory and abortive; they eventually form dystrophic endbulbs and growth-associated proteins are down-regulated after a few days [36].
Such observations have led to the conclusion that the lack of substantial functional recovery after large brain or spinal cord injuries is caused by ineffective regeneration of lesioned axons, the regeneration being limited by neurite growth inhibitors. The immediate questions brought about by the discovery of inhibitory factors and in particular the protein Nogo-A were: (1) Would the functional blockade of Nogo-A signalling after CNS injury increase the otherwise abortive regenerative response and allow axons to regenerate over longer distances? (2) Could regeneration together with the potential increase in compensatory fibre growth and circuit plasticity lead to improved functional recovery?

Experiments from various laboratories over more than 10 years suggest that the answer to both questions is yes. Neutralizing Nogo-A either by applying function-blocking antibodies directed against the N-terminal region of Nogo-A or by interfering with Nogo-A receptors or signalling pathways boosts the regenerative response of injured adult CNS tracts, stimulates compensatory fibre growth and improves the recovery of lost functions [9-11, 62, 108-111].

Four different lines of transgenic animals lacking Nogo-A, Nogo-A and -B or Nogo-A, -B and -C generated by three independent laboratories yielded somewhat conflicting results [112]. Whereas the Nogo-A [113] and the Nogo-A and -B [114] knockout lines showed an increased regenerative phenotype, with an increased number of CST fibres growing from the end of the severed CST towards the lesion site in the former, and fibres regenerating into distal cord segments in the latter, the Nogo-A and -B and Nogo$\mathrm{A},-\mathrm{B}$ and $-\mathrm{C}$ knockout mice of the third laboratory did not seem to show increased regeneration [115]. Follow-up studies showed that the genetic background of different mouse lines [116], compensatory upregulation of other Nogo proteins [113] and the lesion paradigms used [117] may account for some of the discrepancies in the findings between the different lines.

Recently, Steward et al. [118] argued that the increased regeneration in the Nogo-A/B knockout mice described by Kim et al. [114] might in part be based on artefactual labelling of axons due to accidental injection or leakage of the tracer into the cerebrospinal fluid in the cerebral ventricle. In response, Cafferty et al. [119] pointed out that this labelling artefact was rare (5\% of traced mice) and the vast majority of the Nogo-A/B knockout mice used for their study bore no resemblance to the labelling pattern of Steward. If the rare mice with such a pattern were excluded from the axon counts, the same statistically valid conclusions remained [119]. In our laboratory, such artefactual labelling of 
axons resulting from incorrect tracing techniques has never been observed.

After large but incomplete SCI and treatment with anti-Nogo-A antibodies, two principal axonal repair mechanisms were observed. Using reconstructions from uninterrupted serial section series, cut axons were seen to regenerate around and beyond the lesion site and to grow through the denervated spinal cord for long distances (typically more than 1-2 mm). They crossed the injury site on bridges of spared tissue and could form extensive terminal arbours in the caudal spinal cord. Corticospinal and serotonergic fibres were studied most intensively $[9,10,108,120,121]$ (Fig. 1).

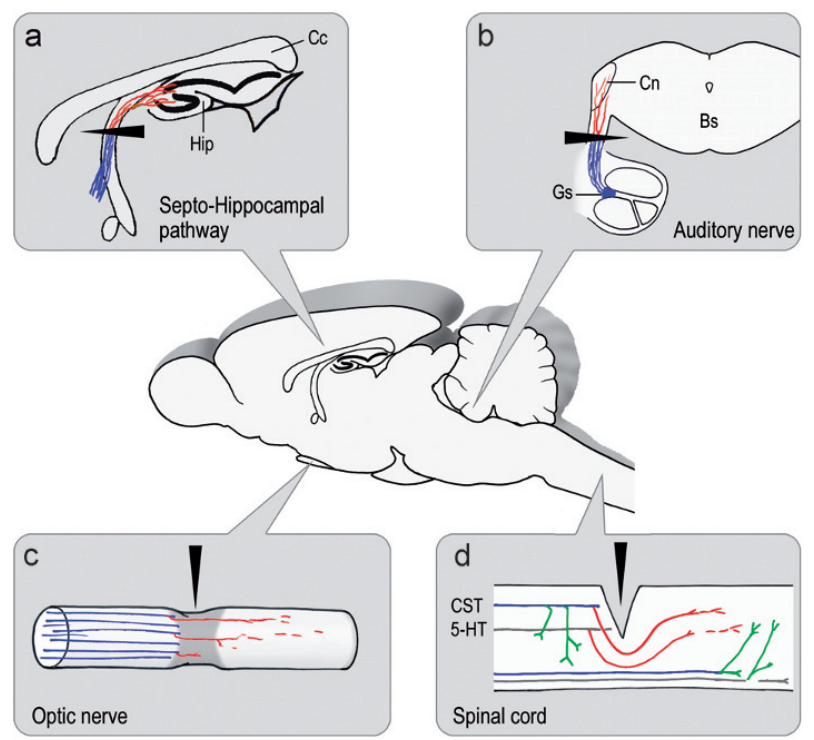

Figure 1. Regenerative axon growth after different CNS lesion paradigms is increased after anti-Nogo-A antibody or $\mathrm{NgR}$ antagonist treatment. Lesion sites are indicated with black arrow heads. Red $=$ regenerated axons. $(a)$ Cholinergic axons regenerate after damage to the septo-hippocampal projection and reinervate their original terminal areas in the hippocampus (Hip) [124]. Blue $=$ cut axons; Cc, corpus callosum. (b) Cochlear fibres, originating from the ganglion spirale (Gs) in the cochlea, regenerate after an auditory nerve transection; some fibres reach their correct target nuclei in the brainstem (Bs) [127]. Blue = cut axons; $\mathrm{Cn}$, cochlear nuclei. (c) Retinal ganglion cell axons regenerate after a freeze-crush lesion of the optic nerve after combined fibroblast growth factor or brain-derived neurotrophic factor and anti-NogoA antibody treatment [126] or after suppressing $\mathrm{NgR}$ activity with a dominant-negative construct transfected into retinal ganglion cell axons [125]. Blue $=$ cut axons. $(d)$ Spinal cord: after dorsal bilateral hemisection of the thoracic spinal cord, cut corticospinal tract axons (blue) regenerate through bridges of spared tissue and grow $1-2 \mathrm{~cm}$ below the lesion site and spared CST axons sprout collaterals below the lesion site after treatment with anti-Nogo-A antibodies [9, 120,121] or blocking NgR [133] or blocking RhoA and ROCK $[62,111]$; lesioned and/or spared 5-HT fibres (grey) regenerate/sprout vigorously below the injury site [10, 133]. Blue $=$ spared and intact CST axons; green $=$ sprouted fibres; 5HT, serotonergic (5-hydroxytryptamine) raphespinal tract.
Alternatively, damaged and/or spared axons were observed to sprout collaterals above and below the injury site. These fibres are typically short (up to $1 \mathrm{~mm}$ ) and can innervate nearby targets, e.g. areas that were denervated by the lesion. This repair mechanism is referred to as collateral or compensatory sprouting (Fig. 2). Below we describe in more detail the recovery process mediated by the neutralization of Nogo-A.

\section{Damaged CNS fibres regenerate after blocking Nogo-A function}

In 1990, Schnell and Schwab [9] reported that neutralizing Nogo-A with function-blocking monoclonal antibodies in rats after an incomplete experimental SCI increased the regeneration of cut axons. They implanted anti-Nogo-A-antibody-producing hybridoma cells into the brain of young, adult rats and transected the dorsal two-thirds of the thoracic spinal cord, including the CST. As a consequence of the treatment, the CST, a major motor and sensory pathway that originates in the sensorimotor cortex and projects to the spinal cord, regenerated up to $11 \mathrm{~mm}$ beyond the injury site (Fig. 1d). In contrast, control animals, treated with antibodies against an unrelated protein, rarely regenerated their CST fibres beyond $0.5-1 \mathrm{~mm}$.

These experiments were repeated in a more clinically relevant setting. Specifically, highly purified monoclonal antibodies directed against the $\mathrm{N}$-terminal region of Nogo-A were applied via a small intrathecal lumbar catheter directly into the cerebrospinal fluid. The results were similar: the number of regenerated CST fibres was much higher in anti-Nogo-A-antibodytreated animals than in control animals [120]. The antibodies that have been used in these studies specifically recognize the Nogo-A-specific domain in the middle of the Nogo-A molecule, thereby blocking the binding of Nogo-A with a putative Nogo-Aspecific receptor (see above). Due to the large size of $\mathrm{IgG}$ antibodies, steric blockade of the Nogo-A-NgR interaction could occur as well. In addition, antibodyinduced internalization and subsequent degradation of cell surface Nogo-A decreases the total tissue levels of Nogo-A and may indirectly contribute to the plasticity-enhancing effects of intrathecally applied anti-Nogo-A antibodies in CNS-injured animals [122].

Other approaches to block Nogo functions, e.g. by blocking $\mathrm{NgR}$ with a blocking peptide (NEP1-40) or by targeting downstream effectors that are shared by other neurite growth inhibitors, e.g. RhoA and ROCK, with blocking compounds yielded comparable results with respect to CST regeneration $[62,108$, 111] (Fig. 1d). 


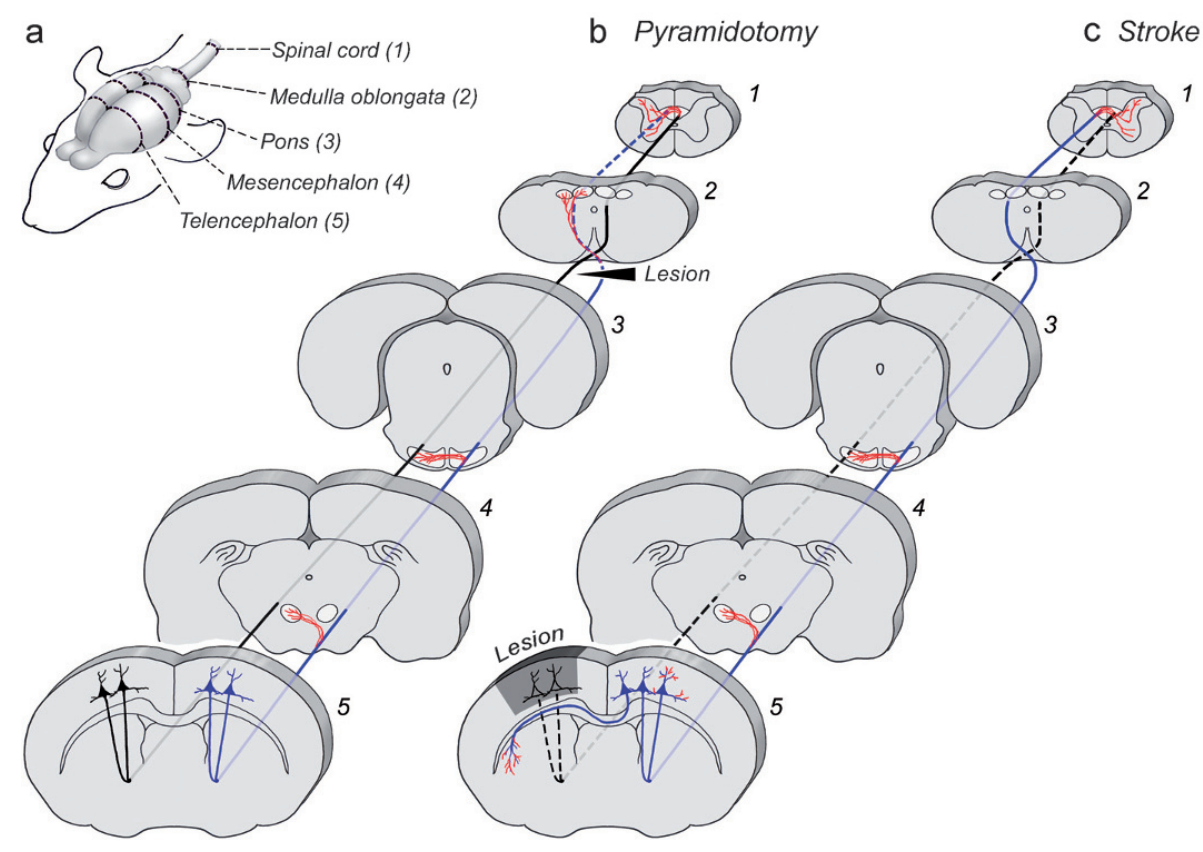

Figure 2. Plastic changes in corticofugal projections that are induced or increased by anti-Nogo-A antibody treatment after spinal cord injury $(b)$ and stroke $(c)$. (a) The overview shows the location of the coronal brain and spinal cord sections. The CST and corticostriatal fibres originating in the left cortex and descending (mainly) in the right half of the spinal cord are in blue, the opposite CST is in black. Dashed lines indicate the degenerated CST below the disruption site. Red, sprouting axons $(b / c) 1-5)$ and dendrites $(c 5)$. $(b)$ Pyramidotomy: a unilateral pyramidotomy (black arrowhead) interrupts selectively the CST on one side at the level of the medulla oblongata (b2) before it decussates. Above the lesion, the affected CST grows midline crossing collaterals to the red nucleus ( $b 4)$ and the basilar pontine nuclei $(b 3)[11,130,131]$. In the medulla (b2), the dorsal column nuclei are reinervated [11]. The unlesioned CST sprouts across the midline in the spinal cord (b1) and reinervates the grey matter after anti-Nogo-A antibody treatment [11]. Similar results were found in $\mathrm{ngr}^{-/}$and nogo-a/ $/ \mathrm{b}^{-/-}$mice [117]. (c) stroke: spared corticospinal tract fibres are seen to sprout to the contralateral side that was denervated by the stroke at several levels. In the mesencephalon $(c 4)$ they grow to the contralateral red nucleus, in the pons to the contralateral basilar pontine nuclei $(c 3)$, and in the spinal cord to the contralateral grey matter $(c 1)[109,110,140,141,155]$. In the telencephalon (c5), corticofugal fibres increase the innervation of the contralateral dorsal striatum [154]. Apical and basilar dendrites of contralesional layer $\mathrm{V}$ pyramidal neurons arbourize to a greater degree [157].

So far most studies have focused on the regeneration of CST neurons because their origin, the sensorimotor cortex, is readily accessible for neuroanatomical tract tracing. However, the regenerative potential may not be equal for different spinal tracts.

Another descending pathway with crucial modulatory function for motor, sensory and autonomic circuits in the spinal cord, the serotonergic raphespinal tracts, also responded vigorously to Nogo-A blocking treatment after a large partial spinal cord lesion: the density of 5-HT fibres below the injury site recovered substantially, reaching normal, preinjury levels in some studies [10, 108, 123] (Fig. 1d). Many fibres may have regenerated but some may also have sprouted from intact fibres that were not interrupted by the injury. Other descending pathways originating from the brainstem, such as the vestibulospinal and reticulospinal tract, are crucial for locomotor functions, yet their response to Nogo-A inactivation has not been studied.

Other important CNS pathways have been studied for their potential to regenerate after Nogo-A neutralization. In a paradigm for axonal injury in the hippo- campus, the regeneration of cut cholinergic septohippocampal axons was boosted substantially by antiNogo-A antibodies [124] (Fig. 1a). Similar results were found after a crush lesion of the optic nerve. Suppressing $\mathrm{NgR}$ activity with a dominant-negative $\mathrm{NgR}$ construct transfected into retinal ganglion cells led to an enhanced regeneration of retinal ganglion cell axons when combined with stimulation by macrophage-derived factors [125]. Increased regeneration of retinal ganglion cells was also seen after application of anti-Nogo-A antibodies combined with brainderived neurotrophic factor [126] (Fig. 1c). Equivalent effects were seen with a recombinant Fab fragment of an anti-Nogo-A antibody after cochlear nerve lesion: cochlear fibres regenerated substantially, and some fibres reached their correct target nuclei in the brainstem. In contrast, control-antibody-treated animals did not show any comparable recovery [127] (Fig. 1b).

These studies show that Nogo-A inactivation promotes axonal regeneration of various types of CNS neurons. Whether qualitative or quantitative differences exist between neurons and tracts with regard 
to Nogo-A suppression remains to be studied in detail.

However, regenerated axons as such are effectively worthless unless they form functional synaptic contacts with appropriate target neurons and integrate correctly into the deafferentiated circuitries below the lesion. Indeed, following dorsal bilateral hemisection and anti-Nogo-A antibody treatment, regenerated axons branched extensively in the grey matter and formed terminal arbours with numerous varicosities, indicating strongly that they established synaptic contacts to target neurons below the injury site [121].

Nevertheless, the often small proportion (typically $5-$ $10 \%$ ) of interrupted fibres that eventually by-passed the lesion site and their variable length (a few millimeters to $1-2 \mathrm{~cm}$ in the rat) indicate that other factors, like the lack of trophic support or the inhibitory glial scar, play additional important roles in preventing axons from regenerating successfully. At the same time, it suggests that other mechanisms, especially compensatory ones, may contribute significantly to functional recovery after large SCIs.

\section{Damaged and spared fibres sprout above and below the SCI site after blocking Nogo-A function}

Most SCIs are incomplete and leave a proportion of axonal projections intact. In young postnatal animals, these spared fibres sprout and form collateral branches below the injury site and may connect to targets that have been left denervated by the SCI [128]. Such new connections are thought to compensate for the lost connections and thereby contribute to the spontaneous functional recovery. The ability to form new collateral connections declines soon after early postnatal life and may be related to myelination (see above) $[96,129]$. Blocking a major inhibitory component of myelin, Nogo-A, in adult animals, increased the ability to sprout new collaterals after SCI (Fig. 2). After a unilateral transection of the CST at the level of the medulla oblongata (pyramidotomy), the contralateral spared CST sprouted and grew into the denervated side of the spinal cord after treatment with antiNogo-A antibodies [11] or if nogo-a/b or ngr [117] was genetically deleted (Fig. 2b). Corticoefferent fibres from the affected side also sprouted across the midline and innervated motor and sensory areas in the contralateral brainstem, including the red nucleus, basilar pontine nuclei and dorsal column nuclei [11, 130, 131] and formed new synaptic contacts [131] (Fig. 2b).

If the CST was transected bilaterally (bilateral pyramidotomy), another descending projection, the rubrospinal tract, originating in the mesencephalic red nucleus, started to form new collateral sprouts in the cervical spinal cord in response to antibodies against Nogo-A [132]. Red nucleus microstimulation confirmed the functionality of these new rubrospinal connections.

\section{Blocking Nogo-A function improves the recovery of motor functions after SCI}

The increased fibre growth in the lesioned CNS after therapeutic interventions is promising, but even more hopeful is the improvement in the recovery of motor function that is correlated with treatments.

Adult rats show some spontaneous recovery after large but incomplete spinal cord lesions, which reaches a plateau after 4-6 weeks. A dorsal bilateral hemisection of the thoracic spinal cord, for example, severely affects hindlimb functions, and the functional recovery is limited. However, if rats were treated with Nogo-A antibodies, these impaired functions recovered faster and to a larger extent, in particular in precision tests, e.g. walking on a narrow beam or crossing a unevenly spaced horizontal ladder. Their ability to swim or to climb a rope was also reported to be improved $[10,120,121]$. Similar results were found when the Nogo receptor subunit $\mathrm{NgR}$ was blocked by the small peptide antagonist NEP 1-40, or when Nogo-A was blocked by $\mathrm{NgR}(319)$ ecto $[108,133,134]$, or by a soluble antagonist of the $\mathrm{NgR}$ co-receptor LINGO-1 [135]. Targeting intracellular mediators of Nogo-A signalling was equally effective: blocking RhoA with C3 transferase or ROCK with a competitive inhibitor (Y-27632) increased the functional recovery after SCI [111]. The effects of blocking these downstream effectors may reflect the consequence of inhibiting several neurite growth inhibitors whose signalling pathways seem to converge to a certain degree.

Substantial improvements in the CST-dependent skilled forelimb use after unilateral pyramidotomy and Nogo-A antibody treatment or knockout have been observed as well [11, 117] (Fig. 3a).

Importantly, common malfunctions after SCI, like pain or spasticity or disturbances in behaviour have not been observed in animals treated with reagents that block the Nogo-Nogo receptor pathway $[33,120$, 136, 137].

\section{Blocking Nogo-A function after stroke and traumatic brain injury}

Equally promising are results gained with animal models for ischaemic stroke. Neutralizing the growth-inhibitory environment of the CNS by blocking Nogo-A function after experimental stroke increased greatly the functional recovery in adult 

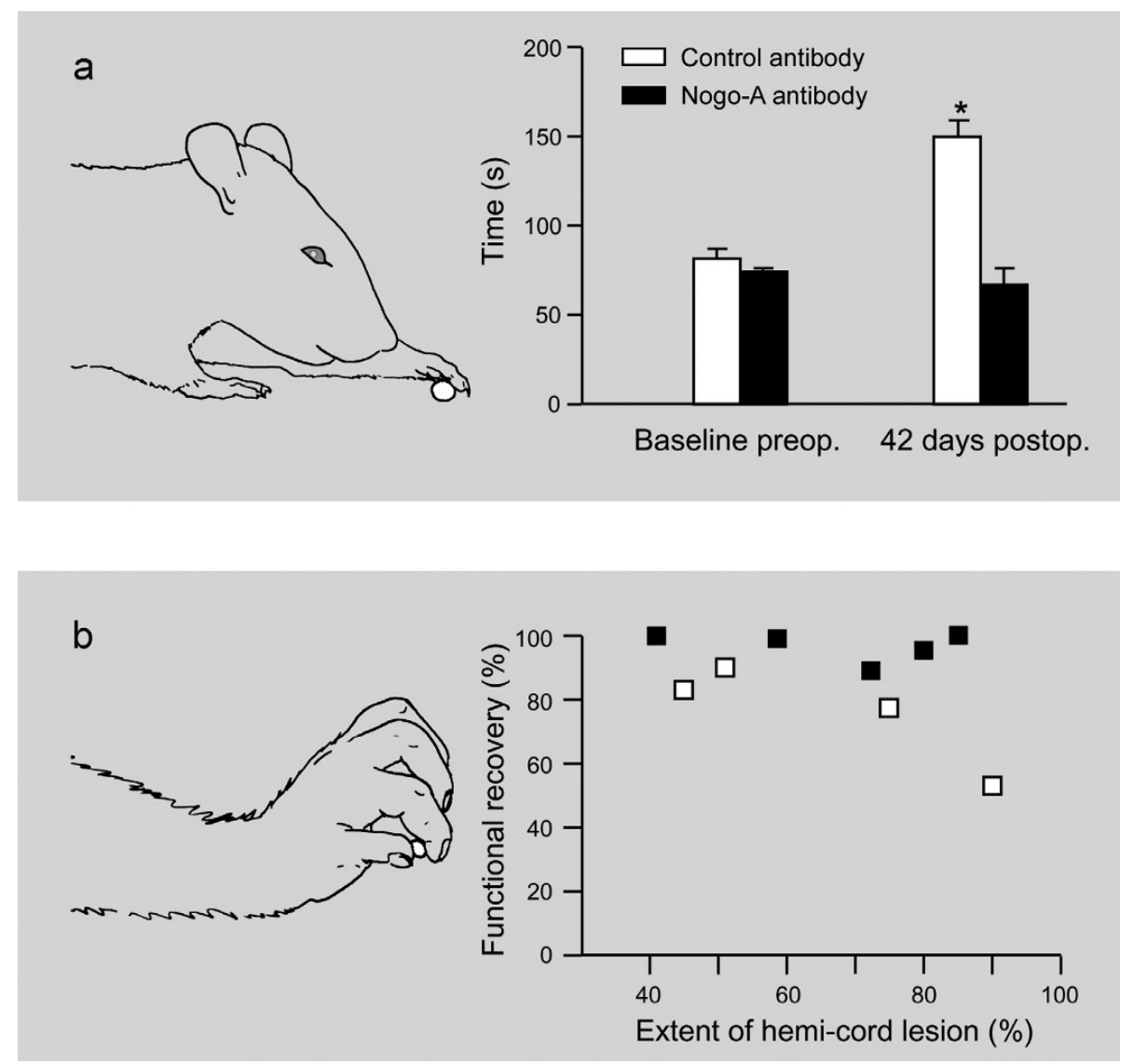

Figure 3. Functional recovery of skilled forelimb/hand use after high CST lesions in the rat $(a)$ and the macaque monkey $(b)$ with and without anti-Nogo-A antibody treatment. (a) Pellet-reaching task. Intact rats require approximately $75 \mathrm{~s}$ to grasp and eat 20 food pellets from a smooth surface (preoperative baseline). Forty-two days after a unilateral CST transection at the level of the pyramid (pyramidotomy), control-antibody-treated rats (white bars) required significantly more time to grasp 20 pellets with their impaired forelimb compared to the preoperative baseline. In contrast, anti-Nogo-A-antibody-treated animals (black bars) recovered to a performance level that did not differ from the preoperative baseline, indicating that the treatment had lead to a substantial functional recovery of precise forelimb usage. Error bars indicate standard error; * $p<0.05$. Adapted by permission from Nature Neuroscience (1998) vol. 1, pp. 124-131, copyright (1998) Macmillan Publishers Ltd. (b) Quantitative assessment of hand dexterity after a unilateral spinal cord lesion at the C7/8 level, aimed at interrupting the main lateral CST. Macaque monkeys were trained to grasp food pellets from horizontally and vertically oriented slots. Immediately after the SCI, their ability to grasp food pellets was severely impaired. Thereafter, the animals recovered partially, reaching a plateau within 30-60 days after injury. For analysis, the average score over 10 days after a stable performance level had been reached (within 30-60 days after injury) was related to the average score over 10 prelesion testing days. The recovery in percentage relative to the prelesion baseline is plotted against the lesion size (percentage hemicord lesion). In anti-Nogo-Aantibody-treated monkeys (black squares), the recovery was complete (or nearly so) irrespective of lesion size, whereas in controlantibody-treated monkeys (white squares) the functional recovery was incomplete and appeared to correlate inversely with the lesion size. Adapted with permission from Nature Medicine (2006) vol. 12, pp. 790-792, copyright (2006) Macmillan Publishers Ltd.

rats. Middle cerebral artery occlusion (MCAO) or photothrombotic brain lesion in the sensorimotor cortex produce large unilateral strokes in rats, which lead to deficits in skilled forelimb use, for example when reaching food pellets $[138,139]$. As in humans, functional deficits persist and the spontaneous recovery of motor functions after large strokes is very limited. However, this recovery was greatly increased after treatment with anti-Nogo-A antibodies $[109,140,141]$ or with $\mathrm{NgR}$ receptor antagonists [110] in rats. Control animals reached about $50 \%$ of the preinjury performance level in tests that assess the skilled forelimb use. In contrast, Nogo-A-anti- body- or NgR-antagonist-treated animals recovered up to $80-100 \%$.

The spontaneous functional improvements after stroke probably involve the opposite intact hemisphere, which compensates for the loss of the infarcted cortical area. Several clinical and experimental studies found that plastic changes in the opposite hemisphere can facilitate motor recovery: in patients who are recovering from large strokes, movements of the paralyzed limb produce an ipsilateral activation of the intact sensorimotor cortex, which is not observed in healthy control subjects [142-145]. Similar changes in cortical activation are found after MCAO or unilat- 
eral cortical ablation in rats [146-148]. Furthermore, in the unmyelinated CNS of newborn rats, unilateral lesions of the sensorimotor cortex led to a substantial increase of contralesional corticofugal projections that cross the midline to innervate denervated motor nuclei in the brainstem and spinal cord [149-153], indicating that the contralesional cortex might take over functions of the injured cortex.

In contrast, adult animals with fully myelinated corticoefferent projections show no or only a minor increase in collateral sprouting of the intact corticospinal tract across the midline after stroke. However, after neutralizing Nogo-A or blocking $\mathrm{NgR}$ in adult rats, the collateral sprouting to the denervated side is greatly increased, mimicking the results gained in newborn animals. The number of corticostriatal fibres projecting from the intact cortex to the contralateral dorsolateral striatum was increased in anti-Nogo-Aantibody-treated rats compared to control animals [154]. In the mesencephalon, the ipsilesional red nucleus, which had lost its ipsilateral cortical afferents, received new, crossed afferents from the intact contralateral cortex [109, 110, 140, 155]. Likewise, the basilar pontine nuclei received more fibres from the intact cortex [140]. At the level of the cervical spinal cord, the number of midline-crossing corticospinal fibres originating from the intact sensorimotor cortex increased significantly [141] and the innervation of the ispilesional medial motoneurons was augmented [156].

In addition to these changes in corticofugal projections, the dendritic arbours of layer $\mathrm{V}$ pyramidal neurons were observed to be altered too: after unilateral MCAO, the contralateral apical and basilar dendrites in Nogo-A-antibody-treated rats had a greater degree of arborization and higher numbers of spines than those of control-antibody-treated rats [157].

Taken together these results suggest that the intact contralesional cortex can gain control over areas denervated by the unilateral cortical lesion. The intact hemisphere forms new and detour connections by sprouting into denervated subcortical motor areas and by contacting other descending tracts that were not affected by the cortical lesion, like the rubrospinal tract. In fact, after unilateral cortical aspiration, electrical stimulation of the intact contralesional cortex resulted in increased activation of ipsilateral forelimb muscles in Nogo-A-antibody-treated animals [158].

Plastic changes are likely to be more widespread and not restricted to the contralesional side. Additional plastic changes take place, for example, in the cortical area adjacent to the infarct and the premotor areas may also be important for the restitution of proper motor functions, especially after smaller lesions [159]. It is probable that blocking Nogo-A function increases spontaneous plastic changes throughout the CNS and thereby improves the functional recovery.

\section{Do the observed anatomical changes account for the functional recovery?}

Achieving successful, i.e. functionally meaningful, regeneration is immensely difficult. New fibres have to integrate into existing, albeit dysfunctional circuitries and accurately connect to appropriate target neurons. Connecting to wrong targets might lead to malfunction with severe consequences, e.g. neurogenic pain, spasticity or epilepsies. Pain and spasticity are common sequelae of SCI and have been associated with erroneous connections that form in the injured spinal cord [160-163].

Proving a causal relationship between plastic anatomical changes and functional improvements is complex and challenging. One way to demonstrate that sprouting and regeneration do account for the enhanced recovery of functions are relesion experiments whereby newly grown connections are selectively destroyed. The concurrent loss of the regained functions would indirectly prove their specific contribution. Bregman et al. [10] showed that the complete removal of the sensorimotor cortex abolished functional improvements after a large mid-thoracic hemisection following anti-Nogo-A antibody treatment. Removing regenerated raphespinal projections with a neurotoxin that selectively kills serotonergic neurons (5,7-dihydroxytryptamine) partly abolished the functional recovery seen in NgR knockout mice [33]. Although theoretically convincing, relesion experiments have an inherent danger of producing false-positive results: selective transection of only the regrown fibres is rarely possible; most lesions are large, damage other pathways and cause a short-term conduction block by oedema and inflammation.

Another approach to prove the functionality and contribution of new connections are electrophysiological experiments. Microstimulation of the rewired rubrospinal tract, which normally does not directly innervate motoneurons projecting to proximal forelimb muscles, elicited short-latency electromyography responses in these muscles, suggesting that direct functional connections were formed [164]. Similarly, transcranial magnetic stimulation of corticospinal motoneurons after an incomplete thoracic lesion showed an increased activation of hindlimb muscles after blockade of $\mathrm{NgR}$ [133]. 
Translating experimental interventions in spinal cord research into clinical studies

A prerequisite for translating a new therapeutic approach to treat SCI from rodents to humans are studies with non-human primates [165]. Their nervous system is more like ours and may react differently to interventional therapies than that of rodents. The CST, for example, has a different anatomy and is more important in monkeys and humans than in rats. Furthermore, the tissue reaction in response to a lesion and the time course of regenerative processes may be different from rodents. Most importantly, monkeys, like humans, are very dexterous in using their hands and fingers and can be trained to do complex behavioural tasks allowing a more refined assessment of motor function. In laboratory macaques, which interact with scientist and animal caretakers very closely during extended behavioural experiments, it is also easier to detect potential side effects of Nogo-A inactivation like pain, spasticity, neuropsychiatric phenomena or changes in social behaviour.

A recent study with 12 adult macaque monkeys has confirmed the efficacy of Nogo-A antibody treatment after SCI in primates [136]. A unilateral cervical hemisection at $\mathrm{C} 7$ led to a substantial loss of ipsilateral manual dexterity. Motor functions in the affected hand, assessed with different tests of dexterity, recovered faster and to a larger extent in anti-Nogo-Aantibody-treated animals (Fig. 3b). No signs of pain or any other side effects were detected. Anatomically, regenerative sprouting of CST axons was observed rostral to the lesion [166].

Translating these experimental findings into clinical studies faces several challenges. The incidence of SCI is low and therefore requires a multi-centre study design to obtain a sufficient number of treated patients. This in turn requires a high level of standardization of protocols between medical centres for a precise diagnosis and the assessment and follow-up of the recovery process. As the functional recovery is a multifaceted process, clinical tests (muscle strength, sensory functions, extent of neurological deficits, neurological level of injury), functional evaluations (walking capacity, hand dexterity, bladder control, ability to live independently) and neurophysiologic assessments (motor and somatosensory evoked potentials) will have to be combined to evaluate accurately the outcome of interventional therapies [167].

Different spinal levels and variable lesion anatomy imply that the population of spinal-cord-injured patients is very heterogeneous with respect to functional deficits and expected functional recovery. This highlights the importance of standardizing the initial clinical and neurophysiological examinations that can reliably estimate the expected outcome and monitor effects of the treatment.

Effective treatment of acute diseases often requires prompt initiation of therapeutic interventions if they are to be successful. Indeed, if the onset of anti-NogoA antibody application after SCI is delayed for 1 or 2 weeks, the therapy is less effective in rats [168]. Accumulation of inhibitory CSPGs around the scar in the days following an injury may prevent axons from growing through or around the spinal cord lesion site. Alternatively or in addition, neurons deprived of their target-derived trophic support can become atrophic and unresponsive to neutralization of Nogo-A.

A future treatment regime for patients with severe SCI will probably require a multidisciplinary approach. After medical and surgical stabilization of the acutely injured patient, the interventional therapies may involve reagents to overcome myelin inhibition, combined with neurotrophic factors to prevent neuronal atrophy and stimulate growth, and treatments that can reduce the growth-suppressive properties of the glial scar. Intensive rehabilitative training programmes will support activity-dependent plastic processes in the CNS and help the patient to regain independence.

A multicentre clinical trial for humanized Nogo-A antibodies in acute SCI is now ongoing in several countries.

Acknowledgements. We thank E. Hochreutener for the help with figures and M. Starkey and A. Lesslauer for critically commenting on the manuscript. This work was supported by a fellowship of the Fondation Louis-Jeantet de Médecine to R. R. Gonzenbach and grants of the Swiss National Science Foundation (grant number 3163633.00), the NCCR Neural Plasticity and Repair of the Swiss National Science Foundation, and the Spinal Cord Consortium of the Christopher Reeve Paralysis Foundation (Springfield, N.J.).

1 Ramón y Cajal, S. R. (1991) Degeneration and Regeneration of the Nervous System, Oxford University Press, Oxford.

2 Davies, S. J., Field, P. M. and Raisman, G. (1996) Regeneration of cut adult axons fails even in the presence of continuous aligned glial pathways. Exp. Neurol. 142, 203-216.

3 David, S. and Aguayo, A. J. (1981) Axonal elongation into peripheral nervous system 'bridges'after central nervous system injury in adult rats. Science 214, 931-933.

4 Schwab, M. E. and Thoenen, H. (1985) Dissociated neurons regenerate into sciatic but not optic nerve explants in culture irrespective of neurotrophic factors. J. Neurosci. 5, 24152423.

5 Caroni, P. and Schwab, M. E. (1988) Two membrane protein fractions from rat central myelin with inhibitory properties for neurite growth and fibroblast spreading. J. Cell Biol. 106, $1281-1288$.

6 Spillmann, A. A., Bandtlow, C. E., Lottspeich, F., Keller, F. and Schwab, M. E. (1998) Identification and characterization of a bovine neurite growth inhibitor (bNI-220). J. Biol. Chem. 273, 19283-19293. 
7 Chen, M. S., Huber, A. B., van der Haar, M. E., Frank, M. Schnell, L., Spillmann, A. A., Christ, F. and Schwab, M. E. (2000) Nogo-A is a myelin-associated neurite outgrowth inhibitor and an antigen for monoclonal antibody IN-1. Nature 403, 434-439.

8 Caroni, P. and Schwab, M. E. (1988) Antibody against myelinassociated inhibitor of neurite growth neutralizes nonpermissive substrate properties of CNS white matter. Neuron 1,8596.

9 Schnell, L. and Schwab, M. E. (1990) Axonal regeneration in the rat spinal cord produced by an antibody against myelinassociated neurite growth inhibitors. Nature 343, 269-272.

10 Bregman, B. S., Kunkel-Bagden, E., Schnell, L., Dai, H. N. Gao, D. and Schwab, M. E. (1995) Recovery from spinal cord injury mediated by antibodies to neurite growth inhibitors. Nature 378, 498-501.

11 Thallmair, M., Metz, G. A., Z'Graggen, W. J., Raineteau, O., Kartje, G. L. and Schwab, M. E. (1998) Neurite growth inhibitors restrict plasticity and functional recovery following corticospinal tract lesions. Nat. Neurosci. 1, 124-131.

12 GrandPre, T., Nakamura, F., Vartanian, T. and Strittmatter, S. M. (2000) Identification of the Nogo inhibitor of axon regeneration as a Reticulon protein. Nature 403, 439-444.

13 Prinjha, R., Moore, S. E., Vinson, M., Blake, S., Morrow, R., Christie, G., Michalovich, D., Simmons, D. L. and Walsh, F. S. (2000) Inhibitor of neurite outgrowth in humans. Nature 403, $383-384$

14 Dodd, D. A., Niederoest, B., Bloechlinger, S., Dupuis, L., Loeffler, J. P. and Schwab, M. E. (2005) Nogo-A, -B, and -C are found on the cell surface and interact together in many different cell types. J. Biol. Chem. 280, 12494-12502.

15 Voeltz, G. K., Prinz, W. A., Shibata, Y., Rist, J. M. and Rapoport, T. A. (2006) A class of membrane proteins shaping the tubular endoplasmic reticulum. Cell 124, 573-586.

16 Oertle, T., van der Haar, M. E., Bandtlow, C. E., Robeva, A., Burfeind, P., Buss, A., Huber, A. B., Simonen, M., Schnell, L., Brosamle, C., Kaupmann, K., Vallon, R. and Schwab, M. E. (2003) Nogo-A inhibits neurite outgrowth and cell spreading with three discrete regions. J. Neurosci. 23, 5393-5406.

17 Acevedo, L., Yu, J., Erdjument-Bromage, H., Miao, R. Q. Kim, J. E., Fulton, D., Tempst, P., Strittmatter, S. M. and Sessa, W. C. (2004) A new role for Nogo as a regulator of vascular remodeling. Nat. Med. 10, 382-388

18 Miao, R. Q., Gao, Y., Harrison, K. D., Prendergast, J., Acevedo, L. M., Yu, J., Hu, F., Strittmatter, S. M. and Sessa, W. C. (2006) Identification of a receptor necessary for Nogo-B stimulated chemotaxis and morphogenesis of endothelial cells. Proc. Natl. Acad. Sci. USA 103, 10997-11002.

19 Fournier, A. E., GrandPre, T. and Strittmatter, S. M. (2001) Identification of a receptor mediating Nogo-66 inhibition of axonal regeneration. Nature 409, 341-346.

$20 \mathrm{He}$, X. L., Bazan, J. F., McDermott, G., Park, J. B., Wang, K. Tessier-Lavigne, M., He, Z. and Garcia, K. C. (2003) Structure of the Nogo receptor ectodomain: a recognition module implicated in myelin inhibition. Neuron 38, 177-185.

21 Barton, W. A., Liu, B. P., Tzvetkova, D., Jeffrey, P. D. Fournier, A. E., Sah, D., Cate, R., Strittmatter, S. M. and Nikolov, D. B. (2003) Structure and axon outgrowth inhibitor binding of the Nogo-66 receptor and related proteins. EMBO J. 22, 3291-3302.

22 Wang, K. C., Kim, J. A., Sivasankaran, R., Segal, R. and He, Z. (2002) P75 interacts with the Nogo receptor as a coreceptor for Nogo, MAG and OMgp. Nature 420, 74-78.

23 Wong, S. T., Henley, J. R., Kanning, K. C., Huang, K. H., Bothwell, M. and Poo, M. M. (2002) A p75(NTR) and Nogo receptor complex mediates repulsive signaling by myelinassociated glycoprotein. Nat. Neurosci. 5, 1302-1308.

24 Park, J. B., Yiu, G., Kaneko, S., Wang, J., Chang, J., He, X. L., Garcia, K. C. and He, Z. (2005) A TNF receptor family member, TROY, is a coreceptor with Nogo receptor in mediating the inhibitory activity of myelin inhibitors. Neuron $45,345-351$
25 Shao, Z., Browning, J. L., Lee, X., Scott, M. L., ShulgaMorskaya, S., Allaire, N., Thill, G., Levesque, M., Sah, D., McCoy, J. M., Murray, B., Jung, V., Pepinsky, R. B. and Mi, S. (2005) TAJ/TROY, an orphan TNF receptor family member, binds Nogo-66 receptor 1 and regulates axonal regeneration. Neuron 45, 353-359.

26 Mi, S., Lee, X., Shao, Z., Thill, G., Ji, B., Relton, J., Levesque, M., Allaire, N., Perrin, S., Sands, B., Crowell, T., Cate, R. L., McCoy, J. M. and Pepinsky, R. B. (2004) LINGO-1 is a component of the Nogo-66 receptor/p75 signaling complex. Nat. Neurosci. 7, 221-228.

27 Wang, K. C., Koprivica, V., Kim, J. A., Sivasankaran, R., Guo, Y., Neve, R. L. and He, Z. (2002) Oligodendrocytemyelin glycoprotein is a Nogo receptor ligand that inhibits neurite outgrowth. Nature 417, 941-944.

28 Domeniconi, M., Cao, Z., Spencer, T., Sivasankaran, R., Wang, K., Nikulina, E., Kimura, N., Cai, H., Deng, K., Gao, Y., He, Z. and Filbin, M. (2002) Myelin-associated glycoprotein interacts with the Nogo66 receptor to inhibit neurite outgrowth. Neuron 35, 283-290.

29 Liu, B. P., Fournier, A., GrandPre, T. and Strittmatter, S. M. (2002) Myelin-associated glycoprotein as a functional ligand for the Nogo-66 receptor. Science 297, 1190-1193.

30 Yamashita, T., Higuchi, H. and Tohyama, M. (2002) The p75 receptor transduces the signal from myelin-associated glycoprotein to Rho. J. Cell Biol. 157, 565-570.

31 Song, X. Y., Zhong, J. H., Wang, X. and Zhou, X. F. (2004) Suppression of p75NTR does not promote regeneration of injured spinal cord in mice. J. Neurosci. 24, 542-546.

32 Zheng, B., Atwal, J., Ho, C., Case, L., He, X. L., Garcia, K. C., Steward, O. and Tessier-Lavigne, M. (2005) Genetic deletion of the Nogo receptor does not reduce neurite inhibition in vitro or promote corticospinal tract regeneration in vivo. Proc. Natl. Acad. Sci. USA 102, 1205-1210.

33 Kim, J. E., Liu, B. P., Park, J. H. and Strittmatter, S. M. (2004) Nogo-66 receptor prevents raphespinal and rubrospinal axon regeneration and limits functional recovery from spinal cord injury. Neuron 44, 439-451.

34 Huber, A. B., Weinmann, O., Brosamle, C., Oertle, T. and Schwab, M. E. (2002) Patterns of Nogo mRNA and protein expression in the developing and adult rat and after CNS lesions. J. Neurosci. 22, 3553-3567.

35 Wang, X., Chun, S. J., Treloar, H., Vartanian, T., Greer, C. A. and Strittmatter, S. M. (2002) Localization of Nogo-A and Nogo-66 receptor proteins at sites of axon-myelin and synaptic contact. J. Neurosci. 22, 5505-5515.

36 Schwab, M. E. and Bartholdi, D. (1996) Degeneration and regeneration of axons in the lesioned spinal cord. Physiol. Rev. 76, 319-370.

37 Reynolds, R. and Wilkin, G. P. (1988) Development of macroglial cells in rat cerebellum. II. An in situ immunohistochemical study of oligodendroglial lineage from precursor to mature myelinating cell. Development 102, 409-425.

38 Josephson, A., Widenfalk, J., Widmer, H. W., Olson, L. and Spenger, C. (2001) NOGO mRNA expression in adult and fetal human and rat nervous tissue and in weight drop injury. Exp. Neurol. 169, 319-328.

39 Richard, M., Giannetti, N., Saucier, D., Sacquet, J., Jourdan, F. and Pellier-Monnin, V. (2005) Neuronal expression of Nogo-A mRNA and protein during neurite outgrowth in the developing rat olfactory system. Eur. J. Neurosci. 22, 21452158.

40 Al Halabiah, H., Delezoide, A. L., Cardona, A., Moalic, J. M. and Simonneau, M. (2005) Expression pattern of NOGO and $\mathrm{NgR}$ genes during human development. Gene Expr. Patterns $5,561-568$.

41 Hunt, D., Coffin, R. S., Prinjha, R. K., Campbell, G. and Anderson, P. N. (2003) Nogo-A expression in the intact and injured nervous system. Mol. Cell. Neurosci. 24, 1083-1102.

42 Liu, H., Ng, C. E. and Tang, B. L. (2002) Nogo-A expression in mouse central nervous system neurons. Neurosci. Lett. 328, $257-260$. 
43 Mingorance-Le Meur, A., Zheng, B., Soriano, E. and Del Rio, J. A. (2007) Involvement of the myelin-associated inhibitor Nogo-A in early cortical development and neuronal maturation. Cereb. Cortex 17, 2375-2386.

44 Tozaki, H., Kawasaki, T., Takagi, Y. and Hirata, T. (2002) Expression of Nogo protein by growing axons in the developing nervous system. Brain Res. Mol. Brain Res. 104, $111-$ 119.

45 Diekmann, H., Klinger, M., Oertle, T., Heinz, D., Pogoda, H. M., Schwab, M. E. and Stuermer, C. A. (2005) Analysis of the reticulon gene family demonstrates the absence of the neurite growth inhibitor Nogo-A in fish. Mol. Biol. Evol. 22, $1635-1648$.

46 Oertle, T., Klinger, M., Stuermer, C. A. and Schwab, M. E. (2003) A reticular rhapsody: phylogenic evolution and nomenclature of the RTN/Nogo gene family. FASEB J. 17, $1238-1247$.

47 Coggeshall, R. E., Birse, S. G. and Youngblood, C. S. (1982) Recovery from spinal transection in fish. Neurosci. Lett. 32, 259-264.

48 Coggeshall, R. E. and Youngblood, C. S. (1983) Recovery from spinal transection in fish: regrowth of axons past the transection. Neurosci. Lett. 38, 227-231.

49 Yin, H. S. and Selzer, M. E. (1983) Axonal regeneration in lamprey spinal cord. J. Neurosci. 3, 1135-1144.

50 Chernoff, E. A., Stocum, D. L., Nye, H. L. and Cameron, J. A (2003) Urodele spinal cord regeneration and related processes. Dev. Dyn. 226, 295-307.

51 Cohen, A. H., Mackler, S. A. and Selzer, M. E. (1988) Behavioral recovery following spinal transection: functional regeneration in the lamprey CNS. Trends Neurosci. 11, $227-$ 231.

52 Klinger, M., Diekmann, H., Heinz, D., Hirsch, C., Hannbeck von Hanwehr, S., Petrausch, B., Oertle, T., Schwab, M. E. and Stuermer, C. A. (2004) Identification of two NOGO/RTN4 genes and analysis of Nogo-A expression in Xenopus laevis. Mol. Cell. Neurosci. 25, 205-216.

53 Dupuis, L., Gonzalez de Aguilar, J. L., di Scala, F., Rene, F., de Tapia, M., Pradat, P. F., Lacomblez, L., Seihlan, D. Prinjha, R., Walsh, F. S., Meininger, V. and Loeffler, J. P. (2002) Nogo provides a molecular marker for diagnosis of amyotrophic lateral sclerosis. Neurobiol. Dis. 10, 358-365.

54 Jokic, N., Gonzalez de Aguilar, J. L., Dimou, L., Lin, S. Fergani, A., Ruegg, M. A., Schwab, M. E., Dupuis, L. and Loeffler, J. P. (2006) The neurite outgrowth inhibitor Nogo-A promotes denervation in an amyotrophic lateral sclerosis model. EMBO Rep. 7, 1162-1167.

55 Pradat, P. F., Bruneteau, G., Gonzalez De Aguilar, J. L., Dupuis, L., Jokic, N., Salachas, F., Le Forestier, N., Echaniz Laguna, A., Dubourg, O., Hauw, J. J., Tranchant, C., Loeffler, J. P. and Meininger, V. (2007) Muscle Nogo-A expression is a prognostic marker in lower motor neuron syndromes. Ann. Neurol. 62, 15-20.

56 Reindl, M., Khantane, S., Ehling, R., Schanda, K., Lutterotti, A., Brinkhoff, C., Oertle, T., Schwab, M. E., Deisenhammer, F., Berger, T. and Bandtlow, C. E. (2003) Serum and cerebrospinal fluid antibodies to Nogo-A in patients with multiple sclerosis and acute neurological disorders. J. Neuroimmunol. 145, 139-147.

57 Jurewicz, A., Matysiak, M., Raine, C. S. and Selmaj, K. (2007) Soluble Nogo-A, an inhibitor of axonal regeneration, as a biomarker for multiple sclerosis. Neurology 68, 283-287.

58 Fontoura, P., Ho, P. P., DeVoss, J., Zheng, B., Lee, B. J., Kidd, B. A., Garren, H., Sobel, R. A., Robinson, W. H., TessierLavigne, M. and Steinman, L. (2004) Immunity to the extracellular domain of Nogo-A modulates experimental autoimmune encephalomyelitis. J. Immunol. 173, 6981-6992.

59 Karnezis, T., Mandemakers, W., McQualter, J. L., Zheng, B., Ho, P. P., Jordan, K. A., Murray, B. M., Barres, B., TessierLavigne, M. and Bernard, C. C. (2004) The neurite outgrowth inhibitor Nogo A is involved in autoimmune-mediated demyelination. Nat. Neurosci. 7, 736-744.
60 Buss, A., Pech, K., Merkler, D., Kakulas, B. A., Martin, D., Schoenen, J., Noth, J., Schwab, M. E. and Brook, G. A. (2005) Sequential loss of myelin proteins during Wallerian degeneration in the human spinal cord. Brain 128, 356-364.

61 Alabed, Y. Z., Grados-Munro, E., Ferraro, G. B., Hsieh, S. H. and Fournier, A. E. (2006) Neuronal responses to myelin are mediated by rho kinase. J. Neurochem. 96, 1616-1625.

62 Fournier, A. E., Takizawa, B. T. and Strittmatter, S. M. (2003) Rho kinase inhibition enhances axonal regeneration in the injured CNS. J. Neurosci. 23, 1416-1423.

63 Niederost, B., Oertle, T., Fritsche, J., McKinney, R. A. and Bandtlow, C. E. (2002) Nogo-A and myelin-associated glycoprotein mediate neurite growth inhibition by antagonistic regulation of RhoA and Rac1. J. Neurosci. 22, 10368-10376.

64 Lehmann, M., Fournier, A., Selles-Navarro, I., Dergham, P., Sebok, A., Leclerc, N., Tigyi, G. and McKerracher, L. (1999) Inactivation of Rho signaling pathway promotes CNS axon regeneration. J. Neurosci. 19, 7537-7547.

65 Bito, H. (2003) Dynamic control of neuronal morphogenesis by rho signaling. J. Biochem. (Tokyo) 134, 315-319.

66 Yiu, G. and He, Z. (2003) Signaling mechanisms of the myelin inhibitors of axon regeneration. Curr. Opin. Neurobiol. 13, $545-551$.

67 Hata, K., Kubo, T., Yamaguchi, A. and Yamashita, T. (2006) Signaling mechanisms of axon growth inhibition. Drug News Perspect. 19, 541-547.

68 McKerracher, L. and Higuchi, H. (2006) Targeting Rho to stimulate repair after spinal cord injury. J. Neurotrauma 23, 309-317.

69 Hsieh, S. H., Ferraro, G. B. and Fournier, A. E. (2006) Myelin-associated inhibitors regulate cofilin phosphorylation and neuronal inhibition through LIM kinase and Slingshot phosphatase. J. Neurosci. 26, 1006-1015.

70 Bandtlow, C. E., Schmidt, M. F., Hassinger, T. D., Schwab, M. E. and Kater, S. B. (1993) Role of intracellular calcium in NI-35-evoked collapse of neuronal growth cones. Science 259, $80-83$.

71 Sivasankaran, R., Pei, J., Wang, K. C., Zhang, Y. P., Shields, C. B., Xu, X. M. and He, Z. (2004) PKC mediates inhibitory effects of myelin and chondroitin sulfate proteoglycans on axonal regeneration. Nat. Neurosci. 7, 261-268.

72 Hasegawa, Y., Fujitani, M., Hata, K., Tohyama, M., Yamagishi, S. and Yamashita, T. (2004) Promotion of axon regeneration by myelin-associated glycoprotein and Nogo through divergent signals downstream of Gi/G. J. Neurosci. 24, 6826-6832.

73 Koprivica, V., Cho, K. S., Park, J. B., Yiu, G., Atwal, J., Gore, B., Kim, J. A., Lin, E., Tessier-Lavigne, M., Chen, D. F. and He, Z. (2005) EGFR activation mediates inhibition of axon regeneration by myelin and chondroitin sulfate proteoglycans. Science 310, 106-110

74 Schweigreiter, R., Walmsley, A. R., Niederost, B., Zimmermann, D. R., Oertle, T., Casademunt, E., Frentzel, S., Dechant, G., Mir, A. and Bandtlow, C. E. (2004) Versican V2 and the central inhibitory domain of Nogo-A inhibit neurite growth via p75NTR/NgR-independent pathways that converge at RhoA. Mol. Cell Neurosci. 27, 163-174.

75 Monnier, P. P., Sierra, A., Schwab, J. M., Henke-Fahle, S. and Mueller, B. K. (2003) The Rho/ROCK pathway mediates neurite growth-inhibitory activity associated with the chondroitin sulfate proteoglycans of the CNS glial scar. Mol. Cell. Neurosci. 22, 319-330.

76 Jain, A., Brady-Kalnay, S. M. and Bellamkonda, R. V. (2004) Modulation of Rho GTPase activity alleviates chondroitin sulfate proteoglycan-dependent inhibition of neurite extension. J. Neurosci. Res. 77, 299-307.

77 Mukhopadhyay, G., Doherty, P., Walsh, F. S., Crocker, P. R. and Filbin, M. T. (1994) A novel role for myelin-associated glycoprotein as an inhibitor of axonal regeneration. Neuron 13, 757-767.

78 McKerracher, L., David, S., Jackson, D. L., Kottis, V., Dunn, R. J. and Braun, P. E. (1994) Identification of myelin-associ- 
ated glycoprotein as a major myelin-derived inhibitor of neurite growth. Neuron 13, 805-811.

79 Niederost, B. P., Zimmermann, D. R., Schwab, M. E. and Bandtlow, C. E. (1999) Bovine CNS myelin contains neurite growth-inhibitory activity associated with chondroitin sulfate proteoglycans. J. Neurosci. 19, 8979-8989.

80 Schmalfeldt, M., Bandtlow, C. E., Dours-Zimmermann, M. T., Winterhalter, K. H. and Zimmermann, D. R. (2000) Brain derived versican V2 is a potent inhibitor of axonal growth. J. Cell Sci. 113, 807-816.

81 Benson, M. D., Romero, M. I., Lush, M. E., Lu, Q. R., Henkemeyer, M. and Parada, L. F. (2005) Ephrin-B3 is a myelin-based inhibitor of neurite outgrowth. Proc. Natl. Acad. Sci. USA 102, 10694-10699.

82 Goldshmit, Y., Galea, M. P., Wise, G., Bartlett, P. F. and Turnley, A. M. (2004) Axonal regeneration and lack of astrocytic gliosis in EphA4-deficient mice. J. Neurosci. 24, 10064-10073.

83 Moreau-Fauvarque, C., Kumanogoh, A., Camand, E., Jaillard, C., Barbin, G., Boquet, I., Love, C., Jones, E. Y., Kikutani, H., Lubetzki, C., Dusart, I. and Chedotal, A. (2003) The transmembrane semaphorin Sema4D/CD100, an inhibitor of axonal growth, is expressed on oligodendrocytes and upregulated after CNS lesion. J. Neurosci. 23, 9229-9239.

84 Jones, T. B., McDaniel, E. E. and Popovich, P. G. (2005) Inflammatory-mediated injury and repair in the traumatically injured spinal cord. Curr. Pharm. Des. 11, 1223-1236.

85 Morgenstern, D. A., Asher, R. A. and Fawcett, J. W. (2002) Chondroitin sulphate proteoglycans in the CNS injury response. Prog. Brain Res. 137, 313-332.

86 Asher, R. A., Morgenstern, D. A., Shearer, M. C., Adcock, K. H., Pesheva, P. and Fawcett, J. W. (2002) Versican is upregulated in CNS injury and is a product of oligodendrocyte lineage cells. J. Neurosci. 22, 2225-2236.

87 Asher, R. A., Morgenstern, D. A., Fidler, P. S., Adcock, K. H., Oohira, A., Braistead, J. E., Levine, J. M., Margolis, R. U., Rogers, J. H. and Fawcett, J. W. (2000) Neurocan is upregulated in injured brain and in cytokine-treated astrocytes. J. Neurosci. 20, 2427-2438.

88 Levine, J. M. (1994) Increased expression of the NG2 chondroitin-sulfate proteoglycan after brain injury. J. Neurosci. $14,4716-4730$

89 McKeon, R. J., Jurynec, M. J. and Buck, C. R. (1999) The chondroitin sulfate proteoglycans neurocan and phosphacan are expressed by reactive astrocytes in the chronic CNS glial scar. J. Neurosci. 19, 10778-10788.

90 Jones, L. L., Yamaguchi, Y., Stallcup, W. B. and Tuszynski, M. H. (2002) NG2 is a major chondroitin sulfate proteoglycan produced after spinal cord injury and is expressed by macrophages and oligodendrocyte progenitors. J. Neurosci. 22, 2792-2803.

91 Busch, S. A. and Silver, J. (2007) The role of extracellular matrix in CNS regeneration. Curr. Opin. Neurobiol. 17, 120 127.

92 Tang, X., Davies, J. E. and Davies, S. J. (2003) Changes in distribution, cell associations, and protein expression levels of NG2, neurocan, phosphacan, brevican, versican V2, and tenascin-C during acute to chronic maturation of spinal cord scar tissue. J. Neurosci. Res. 71, 427-444.

93 Bradbury, E. J., Moon, L. D., Popat, R. J., King, V. R., Bennett, G. S., Patel, P. N., Fawcett, J. W. and McMahon, S. B. (2002) Chondroitinase ABC promotes functional recovery after spinal cord injury. Nature 416, 636-640.

94 Cafferty, W. B., Yang, S. H., Duffy, P. J., Li, S. and Strittmatter, S. M. (2007) Functional axonal regeneration through astrocytic scar genetically modified to digest chondroitin sulfate proteoglycans. J. Neurosci. 27, 2176-2185.

95 Silver, J. and Miller, J. H. (2004) Regeneration beyond the glial scar. Nat. Rev. Neurosci. 5, 146-156.

96 Kapfhammer, J. P. and Schwab, M. E. (1994) Inverse patterns of myelination and GAP-43 expression in the adult CNS: neurite growth inhibitors as regulators of neuronal plasticity? J. Comp. Neurol. 340, 194-206.

97 Vanek, P., Thallmair, M., Schwab, M. E. and Kapfhammer, J. P. (1998) Increased lesion-induced sprouting of corticospinal fibres in the myelin-free rat spinal cord. Eur. J. Neurosci. $10,45-56$.

98 Hensch, T. K. (2005) Critical period plasticity in local cortical circuits. Nat. Rev. Neurosci. 6, 877-888.

99 Pizzorusso, T., Medini, P., Berardi, N., Chierzi, S., Fawcett, J. W. and Maffei, L. (2002) Reactivation of ocular dominance plasticity in the adult visual cortex. Science 298, 1248-1251.

100 McGee, A. W., Yang, Y., Fischer, Q. S., Daw, N. W. and Strittmatter, S. M. (2005) Experience-driven plasticity of visual cortex limited by myelin and Nogo receptor. Science 309, 2222-2226.

101 Carulli, D., Laabs, T., Geller, H. M. and Fawcett, J. W. (2005) Chondroitin sulfate proteoglycans in neural development and regeneration. Curr. Opin. Neurobiol. 15, 116-120.

102 Harel, N. Y. and Strittmatter, S. M. (2006) Can regenerating axons recapitulate developmental guidance during recovery from spinal cord injury? Nat. Rev. Neurosci. 7, 603-616.

103 Schwab, M. E. (2004) Nogo and axon regeneration. Curr. Opin. Neurobiol. 14, 118-124.

104 Yiu, G. and He, Z. (2006) Glial inhibition of CNS axon regeneration. Nat. Rev. Neurosci. 7, 617-627.

105 Fawcett, J. W., Curt, A., Steeves, J. D., Coleman, W. P., Tuszynski, M. H., Lammertse, D., Bartlett, P. F., Blight, A. R., Dietz, V., Ditunno, J., Dobkin, B. H., Havton, L. A. et al. (2007) Guidelines for the conduct of clinical trials for spinal cord injury as developed by the ICCP panel: spontaneous recovery after spinal cord injury and statistical power needed for therapeutic clinical trials. Spinal Cord 45, 190205.

106 Raineteau, O. and Schwab, M. E. (2001) Plasticity of motor systems after incomplete spinal cord injury. Nat. Rev. Neurosci. 2, 263-273.

107 Bareyre, F. M., Kerschensteiner, M., Raineteau, O., Mettenleiter, T. C., Weinmann, O. and Schwab, M. E. (2004) The injured spinal cord spontaneously forms a new intraspinal circuit in adult rats. Nat. Neurosci. 7, 269-277.

108 GrandPre, T., Li, S. and Strittmatter, S. M. (2002) Nogo-66 receptor antagonist peptide promotes axonal regeneration. Nature 417, 547-551.

109 Papadopoulos, C. M., Tsai, S. Y., Alsbiei, T., O’Brien, T. E., Schwab, M. E. and Kartje, G. L. (2002) Functional recovery and neuroanatomical plasticity following middle cerebral artery occlusion and IN-1 antibody treatment in the adult rat. Ann. Neurol. 51, 433-441.

110 Lee, J. K., Kim, J. E., Sivula, M. and Strittmatter, S. M. (2004) Nogo receptor antagonism promotes stroke recovery by enhancing axonal plasticity. J. Neurosci. 24, 6209-6217.

111 Dergham, P., Ellezam, B., Essagian, C., Avedissian, H., Lubell, W. D. and McKerracher, L. (2002) Rho signaling pathway targeted to promote spinal cord repair. J. Neurosci. 22, 6570-6577.

112 Woolf, C. J. (2003) No Nogo: now where to go? Neuron 38, $153-156$

113 Simonen, M., Pedersen, V., Weinmann, O., Schnell, L., Buss, A., Ledermann, B., Christ, F., Sansig, G., van der Putten, H. and Schwab, M. E. (2003) Systemic deletion of the myelinassociated outgrowth inhibitor Nogo-A improves regenerative and plastic responses after spinal cord injury. Neuron 38, 201-211.

114 Kim, J. E., Li, S., GrandPre, T., Qiu, D. and Strittmatter, S. M. (2003) Axon regeneration in young adult mice lacking NogoA/B. Neuron 38, 187-199.

115 Zheng, B., Ho, C., Li, S., Keirstead, H., Steward, O. and Tessier-Lavigne, M. (2003) Lack of enhanced spinal regeneration in Nogo-deficient mice. Neuron 38, 213-224.

116 Dimou, L., Schnell, L., Montani, L., Duncan, C., Simonen, M., Schneider, R., Liebscher, T., Gullo, M. and Schwab, M. E. 
(2006) Nogo-A-deficient mice reveal strain-dependent differences in axonal regeneration. J. Neurosci. 26, 5591-5603.

117 Cafferty, W. B. and Strittmatter, S. M. (2006) The Nogo-Nogo receptor pathway limits a spectrum of adult CNS axonal growth. J. Neurosci. 26, 12242-12250.

118 Steward, O., Zheng, B., Banos, K. and Yee, K. M. (2007) Response to: Kim et al., "Axon regeneration in young adult mice lacking Nogo-A/B." Neuron 38, 187-199. Neuron 54 $191-195$.

119 Cafferty, W. B., Kim, J. E., Lee, J. K. and Strittmatter, S. M. (2007) Response to correspondence: Kim et al., "Axon regeneration in young adult mice lacking Nogo-A/B." Neuron 38, 187-199. Neuron 54, 195-199.

120 Liebscher, T., Schnell, L., Schnell, D., Scholl, J., Schneider, R., Gullo, M., Fouad, K., Mir, A., Rausch, M., Kindler, D. Hamers, F. P. and Schwab, M. E. (2005) Nogo-A antibody improves regeneration and locomotion of spinal cord-injured rats. Ann. Neurol. 58, 706-719.

121 Brosamle, C., Huber, A. B., Fiedler, M., Skerra, A. and Schwab, M. E. (2000) Regeneration of lesioned corticospinal tract fibers in the adult rat induced by a recombinant, humanized IN-1 antibody fragment. J. Neurosci. 20, 8061 8068

122 Weinmann, O., Schnell, L., Ghosh, A., Montani, L., Wiessner, C., Wannier, T., Rouiller, E., Mir, A. and Schwab, M. E. (2006) Intrathecally infused antibodies against Nogo-A penetrate the CNS and downregulate the endogenous neurite growth inhibitor Nogo-A. Mol. Cell. Neurosci. 32, 161-173.

$123 \mathrm{Li}, \mathrm{S}$. and Strittmatter, S. M. (2003) Delayed systemic Nogo-66 receptor antagonist promotes recovery from spinal cord injury. J. Neurosci. 23, 4219-4227.

124 Cadelli, D. and Schwab, M. E. (1991) Regeneration of lesioned septohippocampal acetylcholinesterase-positive axons is improved by antibodies against the myelin-associated neurite growth inhibitors NI-35/250. Eur. J. Neurosci. 3, 825832.

125 Fischer, D., He, Z. and Benowitz, L. I. (2004) Counteracting the Nogo receptor enhances optic nerve regeneration if retinal ganglion cells are in an active growth state. J. Neurosci. 24, 1646-1651.

126 Weibel, D., Cadelli, D. and Schwab, M. E. (1994) Regeneration of lesioned rat optic nerve fibers is improved after neutralization of myelin-associated neurite growth inhibitors. Brain Res. 642, 259-266.

127 Tatagiba, M., Rosahl, S., Gharabaghi, A., Blomer, U., Brandis, A., Skerra, A., Samii, M. and Schwab, M. E. (2002) Regeneration of auditory nerve following complete sectioning and intrathecal application of the IN-1 antibody. Acta Neurochir. (Wien) 144, 181-187.

128 Kalil, K. and Reh, T. (1979) Regrowth of severed axons in the neonatal central nervous system: establishment of normal connections. Science 205, 1158-1161.

129 Kuang, R. Z. and Kalil, K. (1990) Specificity of corticospinal axon arbors sprouting into denervated contralateral spinal cord. J. Comp. Neurol. 302, 461-472.

130 Z'Graggen, W. J., Fouad, K., Raineteau, O., Metz, G. A., Schwab, M. E. and Kartje, G. L. (2000) Compensatory sprouting and impulse rerouting after unilateral pyramidal tract lesion in neonatal rats. J. Neurosci. 20, 6561-6569.

131 Blochlinger, S., Weinmann, O., Schwab, M. E. and Thallmair, M. (2001) Neuronal plasticity and formation of new synaptic contacts follow pyramidal lesions and neutralization of NogoA: a light and electron microscopic study in the pontine nuclei of adult rats. J. Comp. Neurol. 433, 426-436.

132 Raineteau, O., Fouad, K., Noth, P., Thallmair, M. and Schwab, M. E. (2001) Functional switch between motor tracts in the presence of the mAb IN-1 in the adult rat. Proc. Natl. Acad. Sci. USA 98, 6929-6934.

133 Li, S., Liu, B. P., Budel, S., Li, M., Ji, B., Walus, L., Li, W. Jirik, A., Rabacchi, S., Choi, E., Worley, D., Sah, D. W. et al. (2004) Blockade of Nogo-66, myelin-associated glycoprotein, and oligodendrocyte myelin glycoprotein by soluble Nogo-66 receptor promotes axonal sprouting and recovery after spinal injury. J. Neurosci. 24, 10511-10520.

134 Li, S., Kim, J. E., Budel, S., Hampton, T. G. and Strittmatter, S. M. (2005) Transgenic inhibition of Nogo-66 receptor function allows axonal sprouting and improved locomotion after spinal injury. Mol. Cell. Neurosci. 29, 26-39.

135 Ji, B., Li, M., Wu, W. T., Yick, L. W., Lee, X., Shao, Z., Wang, J., So, K. F., McCoy, J. M., Pepinsky, R. B., Mi, S. and Relton, J. K. (2006) LINGO-1 antagonist promotes functional recovery and axonal sprouting after spinal cord injury. Mol. Cell. Neurosci. 33, 311-320.

136 Freund, P., Schmidlin, E., Wannier, T., Bloch, J., Mir, A., Schwab, M. E. and Rouiller, E. M. (2006) Nogo-A-specific antibody treatment enhances sprouting and functional recovery after cervical lesion in adult primates. Nat. Med. 12, 790792.

137 Merkler, D., Metz, G. A., Raineteau, O., Dietz, V., Schwab, M. E. and Fouad, K. (2001) Locomotor recovery in spinal cord-injured rats treated with an antibody neutralizing the myelin-associated neurite growth inhibitor Nogo-A. J. Neurosci. $21,3665-3673$.

138 Castro, A. J. (1972) The effects of cortical ablations on digital usage in the rat. Brain Res 37, 173-185.

139 Kartje-Tillotson, G. and Castro, A. J. (1980) Limb preference after unilateral pyramidotomy in adult and neonatal rats. Physiol. Behav. 24, 293-296.

140 Wenk, C. A., Thallmair, M., Kartje, G. L. and Schwab, M. E. (1999) Increased corticofugal plasticity after unilateral cortical lesions combined with neutralization of the IN-1 antigen in adult rats. J. Comp. Neurol. 410, 143-157.

141 Wiessner, C., Bareyre, F. M., Allegrini, P. R., Mir, A. K., Frentzel, S., Zurini, M., Schnell, L., Oertle, T. and Schwab, M. E. (2003) Anti-Nogo-A antibody infusion 24 hours after experimental stroke improved behavioral outcome and corticospinal plasticity in normotensive and spontaneously hypertensive rats. J. Cereb. Blood Flow Metab. 23, 154-165.

142 Johansen-Berg, H., Rushworth, M. F., Bogdanovic, M. D., Kischka, U., Wimalaratna, S. and Matthews, P. M. (2002) The role of ipsilateral premotor cortex in hand movement after stroke. Proc. Natl. Acad. Sci. USA 99, 14518-14523.

143 Chollet, F., DiPiero, V., Wise, R. J., Brooks, D. J., Dolan, R. J. and Frackowiak, R. S. (1991) The functional anatomy of motor recovery after stroke in humans: a study with positron emission tomography. Ann. Neurol. 29, 63-71.

144 Weiller, C., Chollet, F., Friston, K. J., Wise, R. J. and Frackowiak, R. S. (1992) Functional reorganization of the brain in recovery from striatocapsular infarction in man. Ann. Neurol. 31, 463-472.

145 Cramer, S. C., Nelles, G., Benson, R. R., Kaplan, J. D., Parker, R. A., Kwong, K. K., Kennedy, D. N., Finklestein, S. P. and Rosen, B. R. (1997) A functional MRI study of subjects recovered from hemiparetic stroke. Stroke 28, 2518-2527.

146 Dijkhuizen, R. M., Ren, J., Mandeville, J. B., Wu, O., Ozdag, F. M., Moskowitz, M. A., Rosen, B. R. and Finklestein, S. P. (2001) Functional magnetic resonance imaging of reorganization in rat brain after stroke. Proc. Natl. Acad. Sci. USA 98, 12766-12771.

147 Jones, T. A. (1999) Multiple synapse formation in the motor cortex opposite unilateral sensorimotor cortex lesions in adult rats. J. Comp. Neurol. 414, 57-466.

148 Dijkhuizen, R. M., Singhal, A. B., Mandeville, J. B., Wu, O., Halpern, E. F., Finklestein, S. P., Rosen, B. R. and Lo, E. H. (2003) Correlation between brain reorganization, ischemic damage, and neurologic status after transient focal cerebral ischemia in rats: a functional magnetic resonance imaging study. J. Neurosci. 23, 510-517.

149 Hicks, S. P. and D'Amato, C. J. (1970) Motor-sensory and visual behavior after hemispherectomy in newborn and mature rats. Exp. Neurol. 29, 416-438.

150 Castro, A. J. and Mihailoff, G. A. (1983) Corticopontine remodelling after cortical and/or cerebellar lesions in newborn rats. J. Comp. Neurol. 219, 112-123. 
151 Nah, S. H. and Leong, S. K. (1976) Bilateral corticofugal projection to the red nucleus after neonatal lesions in the albino rat. Brain Res. 107, 433-436.

152 Leong, S. K. and Lund, R. D. (1973) Anomalous bilateral corticofugal pathways in albino rats after neonatal lesions. Brain Res. 62, 218-221.

153 Castro, A. J. (1975) Ipsilateral corticospinal projections after large lesions of the cerebral hemisphere in neonatal rats. Exp. Neurol. 46, 1-8.

154 Kartje, G. L., Schulz, M. K., Lopez-Yunez, A., Schnell, L. and Schwab, M. E. (1999) Corticostriatal plasticity is restricted by myelin-associated neurite growth inhibitors in the adult rat. Ann. Neurol. 45, 778-786.

155 Seymour, A. B., Andrews, E. M., Tsai, S. Y., Markus, T. M., Bollnow, M. R., Brenneman, M. M., O'Brien, T. E., Castro, A. J., Schwab, M. E. and Kartje, G. L. (2005) Delayed treatment with monoclonal antibody IN-1 1 week after stroke results in recovery of function and corticorubral plasticity in adult rats. J. Cereb. Blood Flow Metab. 25, 1366-1375.

156 Emerick, A. J. and Kartje, G. L. (2004) Behavioral recovery and anatomical plasticity in adult rats after cortical lesion and treatment with monoclonal antibody IN-1. Behav. Brain Res. $152,315-325$

157 Papadopoulos, C. M., Tsai, S. Y., Cheatwood, J. L., Bollnow, M. R., Kolb, B. E., Schwab, M. E. and Kartje, G. L. (2006) Dendritic plasticity in the adult rat following middle cerebral artery occlusion and Nogo-a neutralization. Cereb. Cortex 16 , 529-536.

158 Emerick, A. J., Neafsey, E. J., Schwab, M. E. and Kartje, G. L. (2003) Functional reorganization of the motor cortex in adult rats after cortical lesion and treatment with monoclonal antibody IN-1. J. Neurosci. 23, 4826-4830.

159 Castro-Alamancos, M. A. and Borrel, J. (1995) Functional recovery of forelimb response capacity after forelimb primary motor cortex damage in the rat is due to the reorganization of adjacent areas of cortex. Neuroscience 68, 793-805.
160 Dietz, V., Wirz, M. and Jensen, L. (1997) Locomotion in patients with spinal cord injuries. Phys. Ther. 77, 508-516.

161 Burchiel, K. J. and Hsu, F. P. (2001) Pain and spasticity after spinal cord injury: mechanisms and treatment. Spine 26, S146-S160.

162 Krenz, N. R. and Weaver, L. C. (1998) Sprouting of primary afferent fibers after spinal cord transection in the rat. Neuroscience $85,443-458$.

163 Gp, M., Austin, G. M., Liu, C. N. and Liu, C. Y. (1958) Sprouting as a cause of spasticity. J Neurophysiol 21, 205-216.

164 Raineteau, O., Fouad, K., Bareyre, F. M. and Schwab, M. E. (2002) Reorganization of descending motor tracts in the rat spinal cord. Eur. J. Neurosci. 16, 1761-1771.

165 Courtine, G., Bunge, M. B., Fawcett, J. W., Grossman, R. G., Kaas, J. H., Lemon, R., Maier, I., Martin, J., Nudo, R. J., Ramon-Cueto, A., Rouiller, E. M., Schnell, L. et al. (2007) Can experiments in nonhuman primates expedite the translation of treatments for spinal cord injury in humans? Nat. Med. 13, 561-566.

166 Freund, P., Wannier, T., Schmidlin, E., Bloch, J., Mir, A., Schwab, M. E. and Rouiller, E. M. (2007) Anti-Nogo-A antibody treatment enhances sprouting of corticospinal axons rostral to a unilateral cervical spinal cord lesion in adult macaque monkey. J. Comp. Neurol. 502, 644-659.

167 Curt, A., Schwab, M. E. and Dietz, V. (2004) Providing the clinical basis for new interventional therapies: refined diagnosis and assessment of recovery after spinal cord injury. Spinal Cord 42,1-6.

168 Gonzenbach, R. R., Schnell, L., Mir, A. K. and Schwab, M. E. (2006) Locomotor recovery and axonal regeneration in experimental spinal cord injury after delayed treatment with monoclonal antibodies against Nogo-A. Annual Meeting of the Society for Neuroscience, Atlanta 2006 www.sfn.org/ am2006/Program\#/Poster\# 585.4/0044.

\section{To access this journal online: http://www.birkhauser.ch/CMLS}

